after which they became finally extinct. The author, in conclusion, referred to the various localities from which he had obtained "conein-cone," and stated that in the Scottish coalfield the structure seems to be always associated with strata in which the contained organisms indicate a freshwater and lacustrine origin for the beds, and that the deposits were therefore probably formed within the areas of wide and shallow lakes.

\title{
CORRESPONTEINCF.
}

\section{THE ENSTATITIC LAVAS OF EYCOTT HILL.}

SiR,-With reference to the interesting paper by Prof. Bonney on the Enstatitic Lavas of Eycott Hill, which appeared in the last Number of this Magazink, I venture to make the following remarks.

At the time when Mr. Ward wrote his memoir on the Geology of the northern part of the Lake District, the term andesite was not in use, except as a synonym for andesine felspar. At that period the rocks now termed andesite were called basalt or dolerite.

The determination of rhombic pyroxene in rocks of this class had not then been made, at all events in this country, and the researches of Whitman Cross, Iddings and Teall bave been published long since Mr. Ward's death. Although, therefore, enstatite exists in the Eycott. Hill Lavas, as now shown by Prof. Bonney, it is not surprising that Mr. Ward did not suspect its presence. This is the less to be wondered at when we consider that he laboured under the great disadvantage of working with a microscope which had no rotating stage or appliances for determining the precise directions of extinction in crystals.

It is, I think, only justice to a departed friend and colleague to offer these explanations.

Frank Rutley.

93, Edith Road, West Kensington.

\section{THEORY OF FAULTS.}

Sir,-I have referred to Captain Hutton's note on Malta, and quite agree with him that the explanation he gives of downward ending faults may be the right one. What I inquired was, if any geologists knew of upward-ending faults in one set of strata?

While I am writing on this subject, will you allow me to add that as some of my friends have expressed disapproval of the tone of $\mathrm{my}$ criticisms on Mr. Fisher's paper, I regret that I was led to adopt it. I had no intention of being either personal or offensive.

Doubtless we all have our weaknesses, and if each were to be attacked in a similar manner, harmony would soon be at an end.

Notringham, April 29, 1885.

J. F. BLAKE.

HOMALONOTUS CRASSICAUDA, SANDB, FROM SOUTH DEVON.

Sir,-The remains of Homalonoti from British Devonian beds, which were known at the time, having been described by yourself in the Geol. MAG. for November, 1881, and April, 1882, it appears to 